\title{
PERBANDINGAN KUALITAS HIDUP PENDERITA KANKER OVARIUM EPITELIAL YANG DIBERIKAN KEMOTERAPI REGIMEN PACLITAXEL DAN CARBOPLATIN DENGAN REGIMEN CYCLOPHOSPAMIDE, ADRIAMICYN DAN CISPLATIN DI RSUP DR. SARDJITO
}

\author{
Ibnu Ahyar ${ }^{1}$, Irwan T. Rachman², Ardhanu Kusumanto ${ }^{3}$
}

\begin{abstract}
Background: Epithelial ovarian cancer is the dominant type of ovarian cancer. Platinum and Taxane regiment has been proved to increase the survival rate of ovarian cancer patients

Objective: To compare the quality of life of ovarian cancer patients who got Paclitaxel and Carboplatin regiments with Cyclophosphamide, Adriamycin and Cisplatin regiments and risk factors which influence them

Method: The design of the study was retrospective cohort. The total subjects were 156 ovarian cancer patients who consisted of 79 patients with paclitaxel and carboplatin regiments and dan 77 patients who got cyclophospamide, adriamicyn dan cisplatin regiments in DR. Sardjito hospital, Yogyakarta. The quality of life was measured with EORTC QLQ-C30. The data distribution were tested with KolmogorovSmirnov and analysed with D Chi-Squaretest for categorical data and Mann-Whitney for continuous data. Multivariable Analysis was done with logistic regression.

Result and Discussion: The bivariable analysis of ovarian cancer stage and the quality of life showed that early stage of ovarian cancer patients had quality of life 19,068 times higher than advance stage of ovarian cancer patients ( $R R$ 19,068; 95\% Cl 2,590-140,362). There were signicant differences in quality of life in ovarian cancer patients with low body mass index $<18,5$ compared to normal body mass index as well as the titer of tumor marker Ca125. Multivariable analysis showed that there was no significant difference in quality of life between ovarian cancer patients who got Paclitaxel plus Carboplatin and ovarian cancer patients who got Cyclophospamide, Adriamicyn plus Cisplatin.

Conclusion: there was no significant difference in quality of life between ovarian cancer patients who got Paclitaxel plus Carboplatin and ovarian cancer patients who got Cyclophospamide, Adriamicyn plus Cisplatin in DR. Sardjito Hospital, Yogyakarta.
\end{abstract}

Keywords: Quality of life, ovarian cancer, paclitaxel plus carboplatin regiment, cyclophospamide, adriamicyn plus cisplatin regiment.

\footnotetext{
ABSTRAK ovarium. risiko yang mempengaruhinya.

PPDS Departemen Obstetri \& Ginekologi, FK-UGM/RSUP DR. Sardjito, Yogyakarta

Departemen Obstetri \& Ginekologi, FK-UGM/RSUP DR. Sardjito, Yogyakarta
}

Latar Belakang: Kanker ovarium epitelial marupakan jenis kanker ovarium yang terbanyak. Kemoterapi kombinasi regimen Platinum dan Taxane diketahui meningkatkan angka harapan hidup penderita kanker

Tujuan: Membandingkan kualitas hidup penderita kanker ovarium yang diberikan kemoterapi regimen paclitaxel dan carboplatin dengan regimen cyclophospamide, adriamicyn dan cisplatin serta faktor-faktor 
Metode: Penelitian dengan rancangan kohort retrospektif pada 156 penderita kanker ovarium, terdapat 79 orang telah selesai mendapatkan 3 kali kemoterapi regimen paclitaxel dan carboplatin dan terdapat 77 orang yang mendapat kemoterapi regimen cyclophospamide, adriamicyn dan cisplatin di RSUP DR. Sardjito, Yogyakarta. Penilaian kualitas hidup menggunakan EORTC QLQ-C30. Distribusi data diuji secara analitik dengan Kolmogorov-Smirnov. Data kategorik diuji dengan Chi-Square, sedangkan data kontinyu diuji dengan Mann-Whitney. Analisis mutivariabel menggunakan regresi logistik.

Hasil dan Pembahasan: Dari analisis bivariabel antara stadium kanker ovarium dengan kualitas hidup diperoleh nilai (RR 19,068; 95\% Cl 2,590-140,362) menunjukkan bahwa penderita kanker ovarium stadium awal mempunyai kualitas hidup 19,068 kali lebih tinggi daripada penderita kanker ovarium stadium lanjut. Didapatkan juga bahwa terdapat perbedaan bermakna pada indeks massa tubuh kurang dari normal $<18,5$ dibandingkan dengan indeks massa tubuh $\geq 18,5$ dengan nilai $P=0,040$ ( $R R \quad 0,253 ; 95 \% \mathrm{Cl}$ 1,056-19,356). Terdapat perbedaan nilai Ca125 yang bermakna antara kelompok kualitas hidup tinggi dengan kelompok kualitas hidup rendah. Hasil analisis multivariable rerata kualitas hidup kelompok Paclitaxel, Carboplatin tidak terdapat perbedaan yang bermakna dibandingkan dengan kelompok Cyclophospamide, Adriamicyn, Cisplatin.

Kesimpulan: Tidak ada perbedaan bermakna kualitas hidup penderita kanker ovarium pada jenis kemoterapi antara kombinasi regimen paclitaxel dan carboplatin dengan regimen cyclophospamide, adriamicyn dan cisplatin di RSUP DR. Sardjito Yogyakarta.

Kata kunci: Kualitas hidup, kanker ovarium, regimen paclitaxel dan carboplatin, regimen cyclophospamide, adriamicyn dan cisplatin.

\section{PENDAHULUAN}

Kanker saat ini masih menjadi masalah kesehatan dunia. Kanker ovarium epitelial marupakan jenis kanker ovarium yang terbanyak. ${ }^{1}$ Pengobatan penyakit kanker mempunyai dampak negatif yang merugikan bagi penderita seperti efek samping yang berat yang dialami oleh penderita. Prinsip-prinsip penatalaksanaan kanker ovarium adalah sama dengan prinsip penanganan penyakit keganasan lainnya yaitu pengobatan terhadap lesi primer secara operatif dan penanganan tempat potensial metastasis tumor dengan kemoterapi. ${ }^{2}$

Kemoterapi bisa dilakukan dengan beberapa regimen obat kemoterapi. Kemoterapi kombinasi regimen Platinum dan Taxane diketahui meningkatkan angka harapan hidup penderita kanker ovarium. ${ }^{3}$ Penggunaan regimen kemoterapi golongan Taxane mempunyai efek leukopenia, neutropenia, trombositopenia dan alergi lebih rendah dibandingkan Regimen Cyclophospamide, Adriamicyn dan Cisplatin. ${ }^{4}$

Diagnosis kanker dan terapi penderita kanker dengan sitostatika mempunyai pengaruh yang besar terhadap kualitas hidup penderita. Kualitas hidup penderita sifatnya sangat subjektif dan hanya dapat diukur oleh penderita itu sendiri. ${ }^{5}$

Salah satu alat ukur untuk melihat keberhasilan terapi terutama pada penyakit kronik yang kemungkinan kesembuhannya sangat kecil adalah kualitas hidup. Kanker merupakan suatu penyakit yang luaran terapinya tidak selalu berupa sembuh dari sakit, namun berupa peningkatan kualitas hidup penderita. ${ }^{6}$

Instrumen untuk mengukur kualitas hidup beragam. Salah satu diantaranya adalah EORTC QLQ-C30 (European Organization for the Research and Treatment of Cancer). ${ }^{7}$ 
EORTC QLQ-C30 merupakan kuesioner yang terdiri dari 30 item yang dikembangkan untuk menilai kualitas hidup penderita kanker. QLQ-C30 versi 3,0 merupakan versi yang terbaru dan dipakai untuk semua penelitian baru yang akan dilakukan. Instrumen QLQ-C30 terdiri dari 2 skala status kesehatan global (kualitas hidup), 5 skala fungsi (fisik, peran, emosional, kognitif dan sosial) dan 9 skala gejala (kelelahan, mual/muntah, nyeri, dispnea, gangguan tidur, kehilangan nafsu makan, konstipasi, diare dan kesulitan keuangan).

Skor skala yang tinggi menunjukkan tingkat respon yang lebih tinggi. Skala fungsi dengan skor yang tinggi menunjukkan tingkat fungsional yang tinggi/sehat. Skor yang tinggi untuk kualitas hidup global menunjukkan tingginya kualitas hidup penderita. Namun skor yang tinggi untuk skala gejala menunjukkan tingginya gejala/ masalah yang dikeluhkan oleh penderita. ${ }^{8}$

Saat ini di RSUP DR. Sardjito, menggunakan kemoterapi regimen paclitaxel (golongan taxane) dan Carboplatin (golongan platinum) dan regimen Cyclophospamide, Adriamicyn dan Cisplatin.

\section{METODE}

Penelitian ini adalah penelitian observasional menggunakan rancangan penelitian kohort retrospektif (historical cohort). Subjek penelitian adalah penderita kanker ovarium yang pernah dirawat di divisi onkologi ginekologi RSUP Dr. Sardjito Yogyakarta. Kriteria inklusi dalam penelitian ini adalah penderita kanker ovarium yang pernah dirawat di divisi onkologi ginekologi RSUP Dr. Sardjito Yogyakarta yang sudah ditegakkan diagnosis sesuai hasil pemeriksaan patologi anatomi dan sudah mendapatkan kemoterapi setengah seri (3siklus) regimen paclitaxel dan Carboplatin dan regimen Cyclophospamide+Adriamicyn+Cisplatin.

Kriteria eksklusi dalam penelitian ini adalah penderita kanker ovarium yang disertai dengan keganasan primer lain selain di ovarium, merupakan kanker ovarium yang rekuren atau sudah mendapatkan kemoterapi yang lain sebelumnya, terdapat penyakit penyerta selain kanker ovarium.

Penelitian ini dilakukan dengan mengumpulkan data dari rekam medik penderita kanker ovarium yang dirawat di divisi onkologi ginekologi RSUP Dr. Sardjito Yogyakarta yang memenuhi kriteria inklusi dan eksklusi. Penderita yang masuk sebagai subjek penelitian, yang sudah selesai menjalani setengah seri kemoterapi (3 siklus) yang melakukan kunjungan ulang pemeriksaan Ca 125 di poliklinik Onkologi Ginekologi RSUP dr Sardjito. Penderita yang masuk sebagai subjek penelitian tersebut dilakukan wawancara untuk pengisian formulir penilaian kualitas hidup dengan instrument kuesioner EORTC QLQ-C30. Didapatkan subjek penelitian sebanyak 156 dengan rincian 79 subjek penelitian dari kelompok yang dilakukan kemoterapi regimen Cyclophospamide, Adriamicyn dan cisplatin dan 77 subjek penelitian yang dilakukan kemoterapi regimen paclitaxel dan carboplatin. 
Tabel 1. Penghitungan Skor QLQ-C30 versi 3,0

\begin{tabular}{lcccc}
\hline $\begin{array}{l}\text { Status Kesehatan Global } \\
\text { (Kualitas Hidup) }\end{array}$ & Skala & Jumlah Item & Range $^{\text {a }}$ & Nomor Item $^{\text {nyyyyy}}$ \\
\cline { 2 - 5 } Skala Fungsi & QL2 & 2 & 6 & $29-30$ \\
$\quad$ Fungsi fisik & PF2 & 5 & 3 & $1-5$ \\
Fungsi peran & RF2 & 2 & 3 & $6-7$ \\
Fungsi emosional & EF & 4 & 3 & $21-24$ \\
Fungsi kognitif & CF & 2 & 3 & 20,25 \\
Fungsi sosial & SF & 2 & 3 & $26-27$ \\
Skala Gejala & & & & \\
Kelelahan & FA & 3 & 3 & $10,12,18$ \\
Mual dan muntah & NV & 2 & 3 & $14-15$ \\
Nyeri & PA & 2 & 3 & 9,19 \\
Dispnea & DY & 1 & 3 & 8 \\
Insomnia & SL & 1 & 3 & 11 \\
Kehilangan selera makan & AP & 1 & 3 & 13 \\
Konstipasi & CO & 1 & 3 & 16 \\
Diare & DI & 1 & 3 & 17 \\
Kesulitan keuangan & FI & 1 & 3 & 28 \\
\hline
\end{tabular}

Penilaian masing-masing item pada kuesioner EORTC QLQ-C30 sesuai dengan table diatas. Untuk item skala fungsi yaitu nomor 1-7, 20-27, untuk skala gejala yaitu item nomor 8-19 dan nomor 28 , sedangkan untuk skala kesehatan global yaitu nomor 29 dan nomor 30. Selanjutnya dilakukan penghitungan dengan cara rumus berikut ini. Range adalah selisih kemungkinan nilai maksimal dari Raw Score dengan kemungkinan nilai minimal. Sebagian besar item skornya $1-4$ sehingga range $=3$, kecuali item status kesehatan global (kualitas hidup) skornya $1-7$ sehingga range $=6$. Raw Score (RS) adalah rerata dari komponen item yang berkontribusi terhadap dari jumlah item dalam skala telah dijawab sehingga mendapatkan skor yang valid. Kemudian dilakukan transformasi linier dari 0 100 untuk mendapatkan skor (S) dihitung dengan cara

$$
\left\{1-\frac{(R S-1)}{\text { range }}\right\} \times 100
$$

$S=$ untuk skala fungsional dan

$$
\mathrm{S}=\{(R S-1) / \text { range }\} \times 100
$$

untuk skala gejala dan status kesehatan global (kualitas hidup).

Selanjutnya dilakukan analisis data secara bertahap. Untuk analisis univariabel terhadap setiap variabel yang ada dalam penelitian ini secara deskriptif dengan menghitung distribusi frekuensi, persentase, rerata dan simpangan bakunya untuk mengetahui karakteristik dan komparabilitas subjek penelitian.

Analisis bivariabel terhadap 2 variabel yaitu hubungan antara variabel bebas dengan variabel tergantung menggunakan uji Independent T-test jika distribusi datanya normal atau uji MannWhitney jika distribusi datanya tidak normal. Sedangkan analisis hubungan variabel tergantung dengan variabel luar menggunakan uji ChiSquare jika memenuhi syaratnya, jika tidak maka 
menggunakan uji Fisher untuk tabel $2 \times 2$ atau uji Kolmogorov-Smirnov untuk tabel $2 \times \mathrm{K}$.

Analisis multivariabel terhadap variabel bebas dan tergantung secara bersamasama dengan mengendalikan variabel luar menggunakan analisis regresi logistik. Semua hasil analisis data diolah menggunakan SPSS 17.0 for Windows.

\section{HASIL DAN PEMBAHASAN}

Rerata umur penderita kanker ovarium yang masuk dalam subjek penelitian adalah $48,30 \pm 12,04$ tahun dengan distribusi terbanyak pada usia 50-59 tahun yaitu 50 orang (32,1\%). Sebagian besar subjek penelitian masuk dalam kategori stadium lanjut yaitu sebanyak 85 orang $(54,5 \%)$ dengan paritas terbanyak adalah 1-2 yaitu sebanyak 110 orang (70,5\%). Mayoritas penderita termasuk dalam kategori histopatologi serosum (58,3\%).
Mayoritas penderita memiliki indeks massa tubuh normal yaitu sebanyak 97 orang $(62,2 \%)$, luas permukaan tubuh $<1,6$ yaitu sebanyak 132 orang $(84,6 \%)$. Latar belakang pendidikan penderita sebagian besar adalah pendidikan rendah yaitu sebanyak 85 orang $(54,5 \%)$ dimana pendidikan SD merupakan yang terbanyak yaitu 45 orang (28,8\%). Rerata Ca125 kelompok regimen Cyclophospamide, Adriamicyn dan cisplatin adalah $319,49 \pm 193,77$ dan rerata Ca125 kelompok regimen paclitaxel dan carboplatin adalah $337,84 \pm 282,87$.

Didapatkan hasil bahwa tidak ada perbedaan bermakna diantara subjek kelompok yang mendapatkan kemoterapi kombinasi regimen Cyclophospamide, Adriamicyn dan cisplatin dan regimen paclitaxel dan carboplatin dalam hal umur, stadium kanker ovarium, paritas, interval waktu, indeks massa tubuh, luas permukaan tubuh, pendidikan, jenis histopatologi dan Ca125. 
Tabel 2. Karakteristik subjek penellitian penderita kanker ovarium yang mendapatkan kemoterapi kombinasi regimen cyclophospamide, adriamicyn dan cisplatin serta regimen paclitaxel dan carboplatin

\begin{tabular}{|c|c|c|}
\hline Variable & $\mathrm{N}$ & Prosentase \\
\hline \multicolumn{3}{|l|}{ Umur (tahun) } \\
\hline \multicolumn{3}{|l|}{$48,30 \pm 12,04$} \\
\hline$<55$ & 109 & 69,9 \\
\hline$>55$ & 47 & 30,1 \\
\hline \multicolumn{3}{|l|}{ Interval Waktu (minggu) } \\
\hline$\leq 3$ & 48 & 30,8 \\
\hline$>3$ & 108 & 69,2 \\
\hline \multicolumn{3}{|c|}{ Stadium Kanker Ovarium } \\
\hline Awal (I-IIA) & 71 & 45,5 \\
\hline Lanjut (IIB-IVA) & 85 & 54,5 \\
\hline \multicolumn{3}{|l|}{ Histopatologi } \\
\hline Musinosum & 56 & 35,9 \\
\hline Serosum & 91 & 58,3 \\
\hline Lain-lain & 9 & 5,8 \\
\hline \multicolumn{3}{|l|}{ Paritas } \\
\hline$<3$ & 121 & 77,6 \\
\hline$>3$ & 35 & 22,4 \\
\hline \multicolumn{3}{|c|}{ Indeks Massa Tubuh (BMI) } \\
\hline Underweight $(<18,5)$ & 59 & 37,8 \\
\hline Normal $(18,5-24,9)$ & 92 & 59,0 \\
\hline Overweight $(>24,9)$ & 5 & 3,2 \\
\hline \multicolumn{3}{|c|}{ Luas Permukaan Tubuh (BSA) } \\
\hline$>1,6$ & 24 & 15,4 \\
\hline$<1,6$ & 132 & 84,6 \\
\hline \multicolumn{3}{|l|}{ Pendidikan } \\
\hline Tinggi (SMA-S1) & 71 & 45,5 \\
\hline Rendah (SD-SMP) & 85 & 54,5 \\
\hline \multicolumn{3}{|l|}{ Ca125 } \\
\hline$\leq 275,5$ & 78 & 50,0 \\
\hline$>275,5$ & 78 & 50,0 \\
\hline
\end{tabular}

Pada analisis bivariabel antara variable luar dengan variable tergantung dapatkan bahwa terdapat perbedaan bermakna pada indeks massa tubuh yang underweight dibanding normal dengan nilai $p=0,031$. 
Terdapat juga perbedaan nilai Ca125 yang bermakna antara kelompok kualitas hidup tinggi dengan kelompok kualitas hidup rendah. Kelompok kualitas hidup tinggi memiliki nilai rerata Ca125 lebih kecil dibanding kelompok kualitas hidup rendah. Sedangkan pada variabel umur, interval waktu, jenis histopatologi, paritas, luas permukaan tubuh, dan pendidikan tidak ada perbedaan bermakna antara kelompok kualitas hidup tinggi dengan kelompok kualitas hidup rendah.

Tabel 3. Kualitas hidup penderita kanker ovarium

\begin{tabular}{|c|c|c|c|c|c|c|}
\hline \multirow[t]{2}{*}{ EORTC QLQ-C30 } & \multirow{2}{*}{$\begin{array}{c}\text { Nilai Referensi } \\
\text { Mean } \\
\end{array}$} & \multicolumn{2}{|c|}{$\begin{array}{l}\text { Cyclophospamide+ } \\
\text { Adriamicyn+Cisplatin }\end{array}$} & \multicolumn{2}{|c|}{$\begin{array}{l}\text { Paclitaxel+ } \\
\text { Carboplatin }\end{array}$} & \multirow[t]{2}{*}{$\mathrm{p}$} \\
\hline & & Mean & SD & Mean & SD & \\
\hline $\begin{array}{l}\text { Status Kesehatan Global } \\
\text { (Kualitas Hidup) }\end{array}$ & 54,11 & 53,80 & 14,05 & 54,44 & 14,47 & 0,825 \\
\hline \multicolumn{7}{|l|}{ Skala Fungsi } \\
\hline Fungsi fisik & 80,38 & 79,83 & 14,24 & 80,95 & 14,38 & 0,536 \\
\hline Fungsi peran & 62,39 & 62,66 & 20,71 & 62,12 & 19,24 & 0,794 \\
\hline Fungsi emosional & 81,84 & 81,01 & 15,09 & 82,68 & 16,49 & 0,333 \\
\hline Fungsi kognitif & 63,25 & 63,08 & 19,73 & 63,42 & 19,50 & 0,894 \\
\hline Fungsi sosial & 62,60 & 61,18 & 20,62 & 64,07 & 20,24 & 0,417 \\
\hline \multicolumn{7}{|l|}{ Skala Gejala } \\
\hline Kelelahan & 34,18 & 34,88 & 12,42 & 33,47 & 11,89 & 0,327 \\
\hline Mual dan muntah & 40,06 & 39,87 & 21,91 & 40,26 & 22,19 & 0,938 \\
\hline Nyeri & 36,54 & 33,76 & 19,24 & 39,40 & 23,56 & 0,155 \\
\hline Dispnea & 48,50 & 48,95 & 19,13 & 48,05 & 22,62 & 0,605 \\
\hline Insomnia & 50,64 & 51,90 & 17,50 & 49,35 & 17,62 & 0,350 \\
\hline $\begin{array}{l}\text { Kehilangan selera } \\
\text { makan }\end{array}$ & 50,00 & 48,94 & 16,74 & 51,08 & 17,60 & 0,478 \\
\hline Konstipasi & 46,15 & 45,99 & 17,95 & 46,32 & 18,06 & 0,975 \\
\hline Diare & 48,08 & 50,21 & 17,60 & 45,89 & 19,53 & 0,234 \\
\hline Kesulitan keuangan & 48,72 & 48,52 & 16,71 & 48,92 & 16,74 & 0,883 \\
\hline
\end{tabular}

Bila nilai kualitas hidup $\geq 70,1$ dikelompokkan sebagai kualitas hidup tinggi dan nilai kualitas hidup $<70,1$ dikelompokkan sebagai kualitas hidup rendah lalu dihubungkan dengan jenis kemoterapi sebagai variabel bebasnya, maka diperoleh hasil bahwa tidak ada hubungan yang bermakna antara jenis kemoterapi dengan kualitas hidup $(p=0,386)$, seperti tampak pada tabel berikut ini. 
Tabel 4. Pengaruh jenis kemoterapi terhadap kualitas hidup

\begin{tabular}{|c|c|c|c|c|}
\hline \multirow{2}{*}{ Jenis Kemoterapi } & \multicolumn{2}{|c|}{ Kualitas Hidup } & \multirow{2}{*}{$\mathrm{RR}(95 \% \mathrm{Cl})$} & \multirow{2}{*}{$\mathrm{p}$} \\
\hline & Tinggi & Rendah & & \\
\hline $\begin{array}{l}\text { Ciclophospamide+ } \\
\text { Adriamisin+Cisplatin }\end{array}$ & 6 & 73 & $0,650(0,243-1,739)$ & 0,386 \\
\hline Paclitaxel+Carboplatin & 9 & 68 & & \\
\hline
\end{tabular}

Dalam penelitian ini didapatkan bahwa sebagian besar penderita kanker ovarium jenis epitelial terbanyak berumur antara 50-59 tahun (50/32,1\%), hal ini sesuai dengan penelitian sebelumnya dimana kanker ovarium ditemukan terbanyak pada usia lebih dari 50 tahun. $^{9}$

Stadium terbanyak adalah stadium lanjut $(85 / 54,5 \%)$, hal ini sangat mungkin berkaitan dengan kesadaran pasien dalam hal kesehatan sehingga datang memeriksakan diri sudah dalam kondisi stadium lanjut, sesuai dengan penelitian sebelumnya yang menyebutkan kanker ovarium merupakan penyakit yang gejalanya tidak khas dan sering datang sudah dalam stadium. ${ }^{10}$ Masalah ini didukung oleh tingkat pendidikan pasien pada penelitian ini yang terbanyak adalah pendidikan SD $(45 / 28,8 \%)$

Hasil analisis univariabel menunjukkan bahwa tidak ada perbedaan bermakna diantara kelompok regimen Cyclophospamide, Adriamicyn dan Cisplatin dan regimen Paclitaxel dan Carboplatin dalam hal umur, stadium kanker ovarium, paritas, indeks massa tubuh, luas permukaan tubuh, pendidikan, dan Ca125. Hal ini menunjukkan bahwa data yang didapatkan terdistribusi secara merata.

Dari analisis bivariabel antara variabel luar dengan variabel tergantung diperoleh nilai p untuk stadium yaitu sebesar $0,000(p<0,05)$ sehingga dapat disimpulkan bahwa terdapat perbedaan bermakna antara stadium awal dengan stadium lanjut terhadap kualitas hidup. Nilai RR sebesar
19,068 menunjukkan bahwa penderita kanker ovarium stadium awal mempunyai kemungkinan kualitas hidup tinggi 19,068 kali lebih besar daripada penderita kanker ovarium stadium lanjut. Hal ini sesuai dengan pernyataan dari FIGO bahwa semakin tinggi derajat kanker ovarium maka harapan hidupnya semakin rendah.

Perbedaan bermakna juga didapatkan pada indeks massa tubuh underweight $(\mathrm{BMI}<18,5)$ dengan nilai $p=0,040$. Hal ini sesuai dengan penelitian sebelumnya, disebutkan bahwa penderita kanker membutuhkan nutrisi yang tinggi karena efek peningkatan metabolisme tubuh. Patofisiologi yang menjelaskan terjadinya penurunan indeks massa tubuh pada penderita kanker dapat melalui beberapa proses yaitu peningkatan katabolisme protein, degradasi protein otot dan oksidasi lemak. ${ }^{11}$ Malnutrisi dan penurunan berat badan seringkali terjadi pada penderita kanker, kedua faktor tersebut dapat mempengaruhi respon dan toleransi dari pengobatan dan dapat menurunkan kualitas hidup pasien serta berkaitan dengan buruknya prognosis. ${ }^{12}$

Terdapat perbedaan nilai Ca125 yang bermakna antara kelompok kualitas hidup tinggi dengan kelompok kualitas hidup rendah. Kelompok kualitas hidup tinggi memiliki nilai rerata Ca125 lebih kecil dibanding kelompok kualitas hidup rendah. Hal ini didukung oleh penelitian sebelumnya yang menyebutkan bahwa titer Ca 125 merupakan salah satu faktor yang bisa dipakai untuk menilai perbaikan ataupun 
perburukan dari terapi kanker ovarium, semakin tinggi nilai Ca 125 maka prognosisnya semakin buruk. ${ }^{13}$

Pada analisis bivariable antara regimen Cyclophospamide, Adriamicyn, Cisplatin dengan regimen Paclitaxel dan Carboplatin terhadap kualitas hidup didapatkan nilai (RR 0,650, $95 \% \mathrm{Cl}$ 0,243-1,739) dengan nilai $p=0,386$. meskipun secara statistik tidak bermakna, hal ini sejalan dengan penelitian sebelumnya yang menyebutkan bahwa regimen Paclitaxel dan Carboplatin menunjukkan efektifitas lebih tinggi dibandingkan regimen Cyclophospamide, Adriamicyn, Cisplatin. ${ }^{4}$

Pada analisis multivariable didapatkan rerata kualitas hidup kelompok Paclitaxel, Carboplatin tidak terdapat perbedaan yang bermakna dibandingkan dengan kelompok Cyclophospamide, Adriamicyn, Cisplatin. Dari analisis multivariabel nilai OR untuk variabel jenis kemoterapi sebesar 0,823 untuk Cyclophospamide, Adriamicyn, Cisplatin menunjukkan bahwa kelompok yang diberikan kemoterapi Cyclophospamide, Adriamicyn, Cisplatin memiliki kualitas hidup 0,823 dibanding dengan kelompok yang diberikan kemoterapi Paclitaxel, Carboplatin.

Sejalan dengan penelitian sebelumnya disebutkan bahwa regimen Paclitaxel dan Carboplatin merupakan kombinasi kemoterapi yang toksisitasnya lebih rendah. Disebutkan pula terdapat perbedaan survival rate yang bermakna antara kelompok yang diberikan kemoterapi Cyclophospamide, Adriamicyn, Cisplatin lebih buruk dibanding dengan kelompok yang diberikan kemoterapi Paclitaxel, Carboplatin, setelah satu tahun dari pertama kali pemberian kemoterapi. ${ }^{4}$

Meskipun dalam penelitian ini tidak didapatkan perbedaan bermakna secara statistik, akan tetapi tingkat kualitas hidup penderita kanker ovarium yang menerima kemoterapi kombinasi regimen Cyclophospamide,
Adriamicyn, Cisplatin cenderung lebih rendah, maka peneliti menyarankan untuk memilih kemoterapi kombinasi regimen Paclitaxel dan Carboplatin sebagai lini pertama kemoterapi untuk kanker ovarium.

\section{DAFTAR PUSTAKA}

1. Hilpert, F. et al.,. 2017. Epithelial ovarian cancer. Ther Umsch, 64(7), pp.375-380.

2. Partridge, E.E. \& Barnes, M.N.,. 1999. Epithelial Ovarian Cancer: Prevention, Diagnosis, and Treatment. $\mathrm{Ca}-\mathrm{A}$ cancer Journal for Clinicians.

3. Glaze, S. et al.,. 2013. Dose-dense paclitaxel with carboplatin for advanced ovarian cancer: a feasible treatment alternative. Journal of obstetrics and gynaecology Canada : JOGC = Journal d'obstetrique et gynecologie du Canada: JOGC, 35(1), pp.61-67.

4. Hidaka, T. et al., 2006. Paclitaxel/carboplatin versus cyclophosphamide/ adriamycin/ cisplatin as postoperative adjuvant chemotherapy for advanced endometrial adenocarcinoma. Journal of Obstetrics and Gynaecology Research, 32(3), pp.330-337

5. Michael, M. \& Tannock, I.F., 1998. Measuring health-related quality of life in clinical trials that evaluate the role of chemotherapy in cancer treatment, CMAJ: Canadian Medical Association Journal, 158(13), pp.1727-1734.

6. Bert, S., 1996. Quality of life and pharmacoeconomics in clinical trials.

7. Jensen, S. \& Cella, D., 2014. Quality of Life in Patients with Ovarian Cancer. Advances in Diagnosis and Management of Ovarian Cancer, pp.241-260.

8. Greimel, E.R. et al., 2006. The European Organization for Research and Treatment of Cancer (EORTC) Quality-of-Life questionnaire cervical cancer module.

9. Berners-Price, S.J. \& Appleton, T.G., 2000. The Chemistry of Cisplatin in Aqueous Solution BT Platinum-Based Drugs in Cancer Therapy. In L. R. Kelland \& N. P. Farrell, eds. Totowa, NJ: Humana Press, pp. 3-35.

10. Luvero, D., Milani, A. \& Ledermann, J.A., 2014. Treatment options in recurrent ovarian cancer: latest evidence and clinical potential. Therapeutic advances in medical oncology, 6(5), pp.229-39. 
11. Das, U. et al., 2014. Assessment of nutritional status of gynecological cancer cases in India and comparison of subjective and objective nutrition.

12. Mardas, M. et al., 2015. Dietary habits changes and quality of life in patients undergoing chemotherapy for epithelial ovarian cancer. Supportive care in cancer: official journal of the Multinational Association of Supportive Care in Cancer, 23(4), pp.1015-23.

13. Teng, F.F. et al., 2014. Determinants of quality of life in ovarian cancer survivors: A pilot study. Journal of Obstetrics \& Gynaecology Canada, 36(8), pp.708715. 